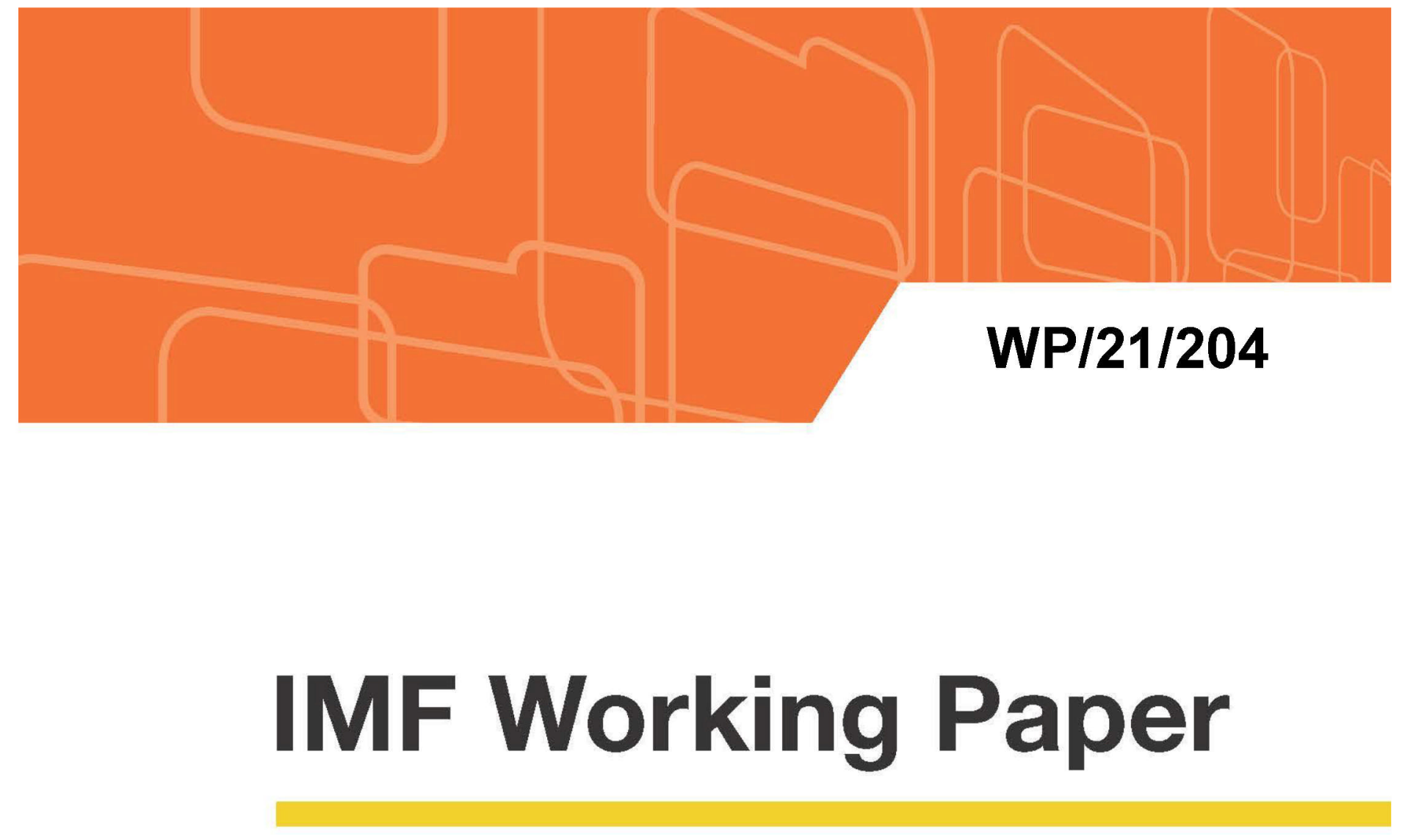

\title{
Sectoral Shocks and Spillovers: An Application to COVID-19
}

by Sonali Das, Giacomo Magistretti, Evgenia Pugacheva, and Philippe Wingender

IMF Working Papers describe research in progress by the author(s) and are published to elicit comments and to encourage debate. The views expressed in IMF Working Papers are those of the author(s) and do not necessarily represent the views of the IMF, its Executive Board, or IMF management. 


\title{
IMF Working Paper
}

Research Department

\section{Sectoral Shocks and Spillovers: An Application to COVID-191}

Prepared by Sonali Das, Giacomo Magistretti, Evgenia Pugacheva, and Philippe Wingender ${ }^{2}$

Authorized for distribution by Malhar Nabar

June 2021

\section{IMF Working Papers describe research in progress by the author(s) and are} published to elicit comments and to encourage debate. The views expressed in IMF Working Papers are those of the author(s) and do not necessarily represent the views of the IMF, its Executive Board, or IMF management.

\begin{abstract}
This paper examines the role of sectoral spillovers in propagating sectoral shocks in the broader economy, both in the past and during the COVID-19 pandemic. In particular, we study how shocks that occur within a sector itself and spillovers from shocks to other sectors affect sectoral activity, for a large sample of countries from 1995 to 2014 . We find that both supply and demand shocks - measured as changes in, respectively, productivity and government purchases at the sector level — have large spillover effects on sector-level gross value added and on a sector's share of the economy. We then use these historical estimates, together with the network structure of global production, to quantify the spillovers from the economic shock associated with the pandemic. We find spillover effects to be sizeable, making up a significant fraction of the overall decline in activity in 2020. Our results have implications for the design of policies with a sectoral dimension.
\end{abstract}

JEL Classification Numbers: D57, E32, F40

Keywords: Production networks, input-output tables, sectoral shocks, spillovers, COVID-19

\footnotetext{
${ }^{1}$ This paper is based on Chapter 2 of the April 2021 World Economic Outlook. For helpful comments and suggestions, we are grateful to John Bluedorn, Gita Gopinath, Petya Koeva Brooks, Weicheng Lian, Malhar Nabar, and numerous seminar participants at the IMF. Srijoni Banerjee and Savannah Newman provided excellent research assistance.

2 Authors' E-Mail Addresses: SDas2@imf.org, GMagistretti@imf.org, EPugacheva@imf.org, PWingender@imf.org.
} 


\section{Table of Contents}

Abstract $\underline{2}$

I. Introduction $\underline{4}$

II. Historical sectoral shocks and their economic effects $\underline{6}$

A. Construction of sectoral shocks

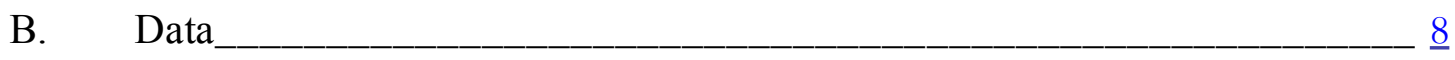

C. Spillovers from historical sectoral shocks _________________________

D. Historical negative sectoral shocks: sector recovery and the role of spillovers $\_\underline{10}$

III. The sectoral dimension of the COVID-19 shock ___________________________

A. Supply and demand components of the COVID-19 shock across sectors

B. Sectoral spillovers in the COVID-19 crisis _________________________

IV. Conclusions and policy implications________________

References ______________________________________________$\underline{19}$

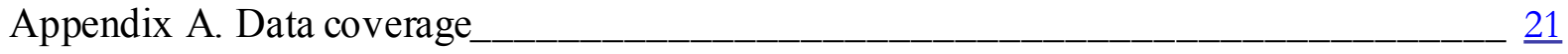

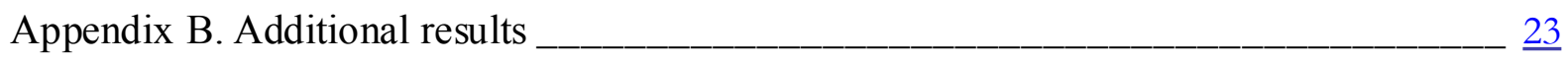

Appendix C. Construction of the COVID-19 shocks ___________________________-_ 24 


\section{Introduction}

The unusual sectoral effects of the COVID-19 pandemic on economies have renewed interest in the propagation and amplification of localized shocks in the aggregate economy. ${ }^{3}$ As the coronavirus spread widely across the globe, so did the economic effects of the containment measures put in place to try to curb its diffusion. The shocks stemming initially from the restrictions to activity in high-contact sectors rapidly spilled over to other industries and to aggregate demand, both domestically and to other countries through trade linkages.

In this paper we study empirically the extent to which shocks originating in certain sectors spill over and end up affecting other sectors, in both the same country and abroad. Recent research has emphasized the importance of economic networks in amplifying shocks (Acemoglu and others, 2016; Acemoglu, Akcigit and Kerr, 2016) and found that complementarities in production can lead sectoral shocks to have large aggregate effects (Foerster, Sarte, and Watson, 2011; Di Giovanni, Levchenko, and Méjean, 2014; Atalay, 2017; Baqaee and Farhi, 2019). Our analysis covers both historical shocks and the recent COVID-19 economic shocks. In the historical analysis, we quantify the size and persistence of sectoral shocks on sectors' subsequent activity and relative size. For COVID-19, our interest is in the size of the spillover effects relative to the direct impact of shocks originating in any given industry.

When looking at the past, we consider both a supply-side shock, in the form of changes in sectoral TFP, and a demand-side shock, in the form of changes in sectoral government purchases. We rely on inter-country input-output tables to quantify the linkages across sectors in the world economy. We find that shocks originating in other industries give rise to substantial and persistent spillover effects on the growth of real gross value added (GVA) in a sector. For supply shocks, total spillover effects traveling from supplier and client sectors are almost twice as large, on average, than the effects from shocks originating within a sector. For demand shocks, they are up to seven times larger. Moreover, a sector's share in a country's GVA remains persistently lower after negative supply shocks, especially for those coming from the same sector.

Our analysis of the COVID-19 shock focuses on the sectoral nature of the crisis and the role that spillovers played in amplifying the initial disruptions. First, we examine the supply and demand dimension of the pandemic shock, differentiating across groups of sectors based on the contact intensity of their activities. Next, we document the differential performance of each sector group in terms of cumulative value-added growth. We show that the downturn was more severe and widespread across industries than during the Global Financial Crisis (GFC) and other recent recessions, but clearly more concentrated and lasting in high-contact sectors, such as accommodation and food services, transportation, and brick-and-mortal retail.

We also quantify the importance of spillovers across sectors in the COVID-19 crisis. By combining actual COVID-19 shocks by country and sector with results from our historical

\footnotetext{
${ }^{3}$ Seminal contributions in this longstanding line of research include Leontief (1951), Hulten (1978), and Long and Plosser (1983).
} 
analysis, we show that almost half of the impact to a given sector can be attributed to spillovers from shocks originating in other sectors, predominantly from shocks to domestic suppliers. Although somewhat smaller than for historical shocks, the estimated spillovers are sizable and demonstrate the meaningful role spillovers played in amplifying the COVID- 19 crisis. ${ }^{4}$ We also document that, as expected, the decline in real gross value added due to spillovers vis-àvis own shocks is larger for low-contact sectors, where the direct impact of lockdowns was less pronounced.

Our paper contributes to the literature on the macroeconomic effects of sectoral - and, more generally, microeconomic - shocks. ${ }^{5}$ This line of research has two main recent delineations. One branch adopts a model-based perspective to study the impact of sectoral shocks on aggregate volatility, macroeconomic tail risk, and output. ${ }^{6}$ Our paper is closer to the second branch of the literature, which takes an empirical approach to the subject. We build on the methodology of Acemoglu, Akcigit, and Kerr (2016) (AKK), who develop an empirical framework to study the impact of various types of domestic network shocks. ${ }^{7}$ As in AAK, we analyze productivity and government spending shocks. We, however, go beyond the US-based analysis of AAK and consider the effects of the shocks for a large number of countries. We also extend the framework to analyze spillovers both within and across countries, by making use of inter-country input-output linkages to construct foreign network shocks. We also derive quantitative implications from past shocks for the COVID-19 crisis.

Our paper is also related to the literature that examines the anatomy of the COVID-19 economic shock (Baqaee and Farhi, 2020 and 2021; Bekaert, Engstrom, and Ermolov, 2020; Brinca, Duarte, and Faria-e-Castro, 2020; del Rio-Chanona and others, 2020; Guerrieri and others, 2020) and its transmission through global value chains (Bonadio and others, 2020; Cerdeiro and Komaromi, 2020).

The rest of the paper is organized as follows. Section II presents the methodology (II.A) and data (II.B) we use to analyze the impact of past sectoral shocks on sectoral GVA (II.C) and the size of a sector (II.D). In Section III we turn to the COVID-19 crisis, first with a primer on the sectoral supply and demand components of the shock (III.A) and then with a quantification of the sectoral spillovers on economic activity (III.B). Section IV concludes and presents some policy implications stemming from the analysis.

\footnotetext{
${ }^{4}$ Finding smaller spillovers for the COVID-19 relative to historical shocks is consistent with the pandemic shock emanating from sectors less central to production networks.

${ }^{5}$ See Carvalho and Tahbaz-Salehi (2019) for a recent survey of this large and growing literature.

${ }^{6}$ Prominent examples include Foerster, Sarte, and Watson (2011), Acemoglu and others (2012), Acemoglu, Ozdaglar, and Tahbaz-Salehi (2017), and Baqaee and Fahri (2019).

${ }^{7}$ There are several other papers, similar in spirit to ours, that empirically study the transmission of natural disaster shocks across firms. They include Barrot and Sauvagnat (2016), Boehm, Flaaen, and Nayar (2019), and Carvalho and others (2021).
} 


\section{Historical sectoral shocks and their economic effects}

In this section we start by detailing the construction of the past sectoral shocks, which expands upon the methodology first proposed in Acemoglu and others (2016) and then refined in AAK. We then provide details on the data used before presenting results on the effects of sectoral shocks on GVA growth and on sectors' recovery from negative shocks.

\section{A. Construction of sectoral shocks}

In the historical sector-level analysis we quantify the size and persistence of sectoral spillovers and rely on inter-country input-output tables to map linkages across sectors. For each sector, we estimate the effects of shocks originated in the same sector (own effect) and in other sectors (spillover effects or network effects).

We call own shocks the shocks originating in any focal sector. We classify shocks from other sectors (together called network shocks) into upstream and downstream, domestic and foreign, based on their origin. Downstream shocks are those originating in supplier sectors that travel downstream to the focal sector, whereas upstream shocks are those originating in customer sectors that travel upstream to the focal sector. Figure 1 provides a graphical representation of a stylized production network for the automotive sector and the various effects for different sectoral shocks. For example, a productivity shock to the steel industry is likely to affect the downstream automotive industry, while a decrease in government purchases of cars will reverberate upstream to the automotive industry.

\section{Figure 1. Own and Spillover Effects}

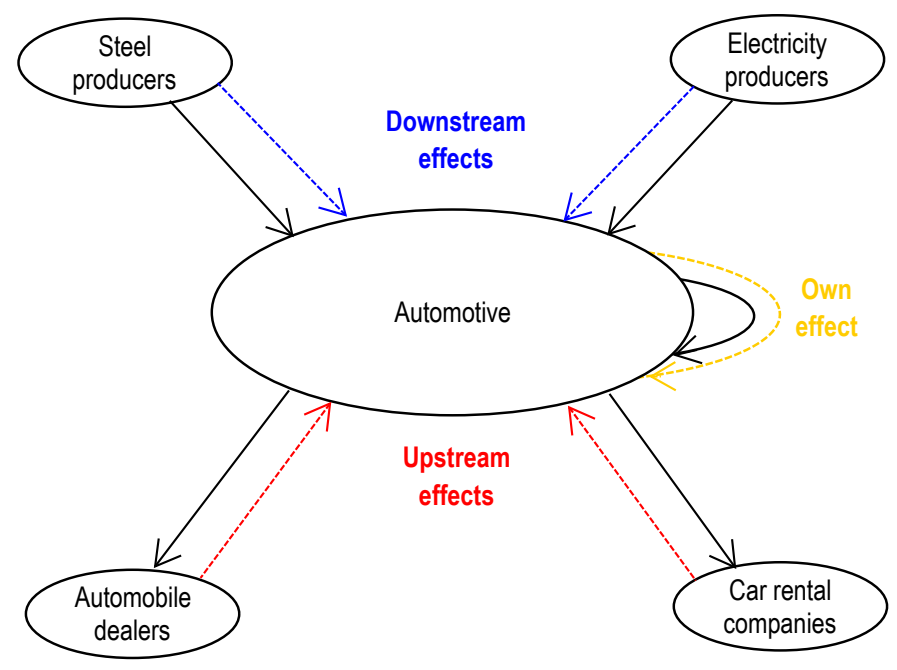

Source: Authors.

Note: Solid, black arrows correspond to (net) trade flows. Dashed, colored arrows correspond to shocks and their resulting effects on the focal sector (automotive). 
Network shocks are further divided into foreign and domestic according to the geographic location of the supplier/customer sector with respect to the focal sector. There are, therefore, four types of network shocks that can hit sector $s$ in country $c$ at time $t$ : upstream domestic $(U p D)$, upstream foreign $(U p F)$, downstream domestic $(D n D)$, and downstream foreign $(D n F)$. We build these shocks from input-output tables based on the following formulas:

$$
\begin{aligned}
\text { Shock }_{s, c, t}^{D n D} & =\sum_{j \neq s} a_{s, c, j, c, 0} \text { Shock }_{j, c, t}^{\text {own }}, \\
\text { Shock }_{s, c, t}^{U p D} & =\sum_{j \neq s} \hat{a}_{s, c, j, c, 0} \text { Shock }_{j, c, t}^{\text {Own }}, \\
\text { Shock }_{s, c, t}^{D n F} & =\sum_{j} \sum_{g \neq c} a_{s, c, j, g, 0} \operatorname{Shock}_{j, g, t}^{\text {own }}, \\
\text { Shock }_{s, c, t}^{U p F} & =\sum_{j} \sum_{g \neq c} \hat{a}_{s, c, j, g, 0} \operatorname{Shock}_{j, g, t}^{O w n},
\end{aligned}
$$

where Shock $k_{j, k, t}^{O w n}$ are own shocks for sector $\mathrm{j}$ in country $k$ at time $\mathrm{t} ; a_{s, c, j, k, t}=\left[\frac{\operatorname{sales}_{(j, k) \rightarrow(s, c), t}}{\operatorname{sales}_{s, c, t}}\right]$ are the sales going from sector $j$ in country $k$ to the focal sector $s$ in country $c$ at time $t$, as a share of total sales of the focal sector; and $\hat{a}_{s, c, j, k, t}=\left[\frac{\text { sales }_{(s, c) \rightarrow(j, k), t}}{{\text { sales } s_{s, c, t}}}\right]$ are the sales of the focal sector $s$ in country $c$ to sector $j$ in country $k$, as a share of total sales of the focal sector. Therefore, downstream shocks - domestic and foreign - are the sum of shocks originating in supplier sectors that travel downstream to the focal sector, weighted by the importance of each supplier sector for the focal sector; whereas upstream shocks - domestic and foreign - are the sum of shocks originating in customer sectors that travel upstream to the focal sector, again weighted by the importance of each customer sector for the focal sector.

We analyze two types of sector-level shocks: a supply shock, proxied by changes in sectoral TFP; and a demand shock, captured by changes in sectoral government purchases. Specifically, the supply-side shock is the year-on-year percentage change in TFP in each sector:

$$
\Delta \log T F P_{s, c, t}=\Delta \log r G V A_{s, c, t}-\alpha_{s, c, t} \Delta \log L_{s, c, t}-\left(1-\alpha_{s, c, t}\right) \Delta \log K_{s, c, t},
$$

where $r G V A_{s, c, t}$ is real gross value added; $L_{s, c, t}$ is total hours worked; $K_{s, c, t}$ is real fixed capital stock; and $\alpha_{s, c, t}$ is the sectoral labor share of value added (calculated as a 2-year moving average). ${ }^{8}$

The demand-side shock is the year-on-year percentage change in government purchases from each sector. In analogy to AAK, we build this shock by weighting the change in real total government spending in country $c$ at year $t$ by the sales of each sector $s$ in country $c$ and year $t-1$ going to either the public administration sector or government consumption in final demand, as a share of sectoral output in $t-1$. Total real government spending in country $c$ at

\footnotetext{
${ }^{8} \mathrm{~A}$ caveat is that TFP shocks constructed as in (5) reflect not only changes in the efficiency of combining inputs, but also any change over time in capacity utilization or in the possible measurement error in the factors of production.
} 
time $t$ is the sum of government consumption and total inputs of the public administration sector in country $c$ at time $t .^{9}$

\section{B. Data}

The historical shocks are built using data from the World Input-Output Database (WIOD). This longitudinal dataset provides input-output tables for the world, divided into up to 43 countries and 56 sectors over the period 1995-2014 (Timmer and others, 2015). The WIOD also contains the corresponding data on employment, capital stocks, gross output and value added. We use data from the 2013 release for the supply-side shock analysis, given that it contains the real variables needed to construct the TFP shock according to (5). We instead combine data from releases 2013 and 2016 to maximize the sample coverage in the analysis of the government spending shocks. Appendix A provides details on the country and sector coverage for each exercise.

\section{Spillovers from historical sectoral shocks}

To quantify the importance of network shocks relative to own shocks in affecting sectoral outcomes, we estimate the following set of local projections (Jordà, 2005):

$$
\Delta^{h} Y_{s, c, t}=\beta^{o w n, h} \operatorname{Shock}_{s, c, t}^{O w n}+\sum_{J} \beta^{J, h} \operatorname{Shock}_{s, c, t}^{J}+\Gamma_{s, c, t}+\varepsilon_{s, c, t}^{h},
$$

where $\Delta^{h} Y_{s, c, t}$ is the cumulative growth in real GVA of sector $s$ in country $c$ between time $t-$ 1 and $t+h$ for government spending shocks, and time $t$ and $t+h$ for TFP shocks. ${ }^{10,11}$ The variable Shock $k_{s, c, t}^{O w n}$ measures the shocks hitting sector $s$ in country $c$ at time $t$ originated in the same sector, whereas Shock $k_{s, c, t}^{J}$ are shocks coming from other parts of the production and distribution network. We consider either the four network shocks defined in (1)-(4) (in which case $J=D n D, D n F, U p D, U p F$ ) or total network shocks, defined as the sum of the four network shocks (in which case $J=$ Tot Nwk). Finally, $\Gamma_{s, c, t}$ is a set of sector, country, and time fixed effects, and $\varepsilon_{s, c, t}^{h}$ is an error term.

The effects of interest - namely, the relative impact that shocks originating in different parts of the network have on a sector's cumulative GVA growth - are given by the various $\beta^{J, h}$. In order to make meaningful comparisons across those coefficients, each shock variable in (6) is divided by its own standard deviation.

Network effects are sizable compared with the own effect for both TFP and government spending shocks. For a productivity shock, total spillover effects are almost two times larger

\footnotetext{
${ }^{9}$ We use the price index for sectoral gross output to deflate nominal government spending. The government spending shock is not derived for the public administration, education, and health sectors, given that changes in government spending directed to those sectors reflect institutional factors more than economic choices.

${ }^{10}$ In all regressions, we cap values of cumulative growth in real GVA larger than $0.5 h$ (smaller than $\left.-0.5 h\right)$ at $0.5 h(-0.5 h)$, to mitigate the effect of outliers.

${ }^{11}$ We chose this timing for the analysis of TFP shocks to exclude the sizable and largely mechanical contemporaneous effect of own TFP shocks on sectoral GVA.
} 
than the own effects, on average (Figure 2, Panel 1, and Table B1, Panel B, in Appendix B). For the government spending shock, spillover effects are broadly the same size as for the supply shock, while own effects are smaller (Figure 2, Panel 2, and Table B2, Panel B, in Appendix B). As a result, the relative size of the spillover effects, compared with the own effect for the government spending shock, is about seven times larger than for the productivity

Figure 2. Own and Total Network Effects of Sectoral Shocks

1) Own and Network Effects of a TFP Shock

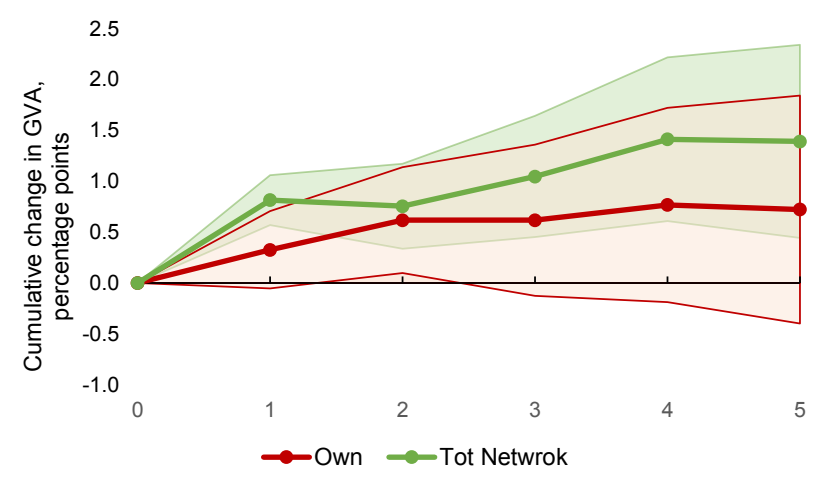

2) Own and Network Effects of a Government Spending Shock

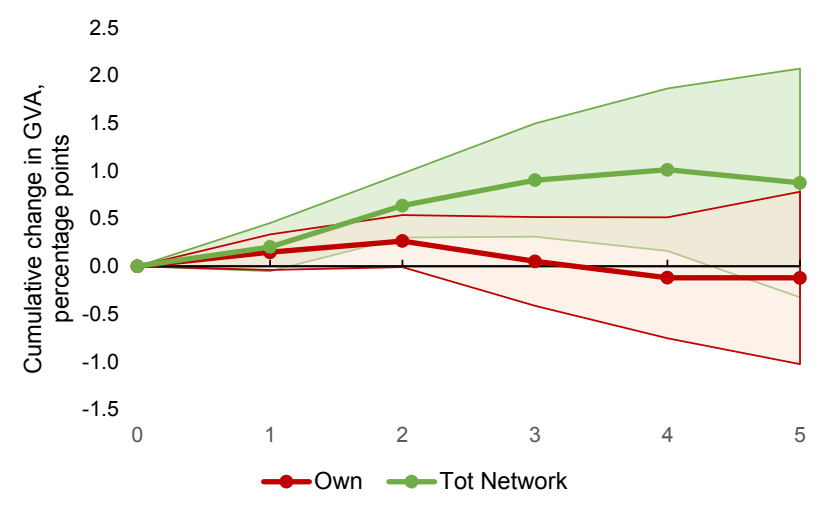

Source: Authors' calculations.

Notes: The labels for the horizons $h$ in the government spending graph have been shifted by one period, to ease the comparison with TFP results.

shock. Spillover effects are persistent for both types of shocks, but especially productivity shocks, remaining sizable up to five years after the shock hits. This means that shocks not only affect activity in sectors in which they originate, but can also have large impacts on connected sectors and generate amplification effects in the case of simultaneous shocks.

Looking at the decomposition of the effects of the different network shocks (Figure 3 and Panels A in Tables B1 and B2 in Appendix B), TFP changes tend to have much larger estimated downstream effects. This result is consistent with earlier literature, as shocks to the productivity of suppliers lead to price changes that in turn affect quantities in the focal sector downstream (see e.g. AAK). We instead do not have evidence in our global sample of the 
dominant role for upstream effects in response to demand shocks found in previous studies focusing on domestic spillovers in the United States.

Figure 3. Own and Spillover Effects from Sectoral Shocks

1) Own and Spillover Effects of a TFP Shock

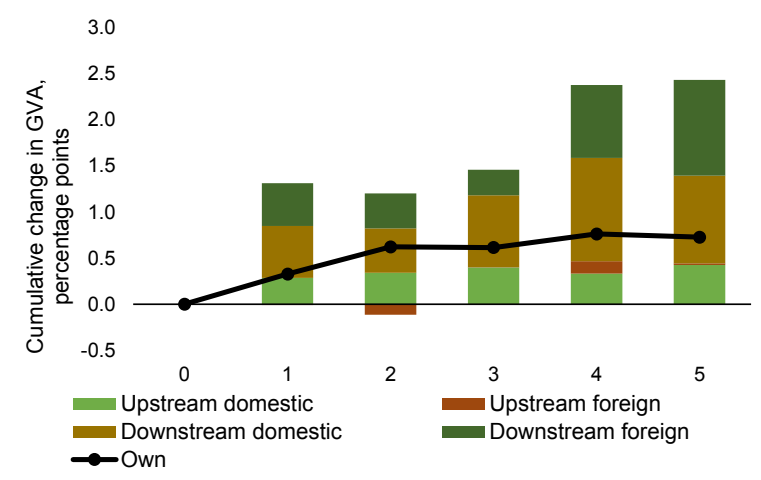

2) Own and Spillover Effects of a Government Spending Shock

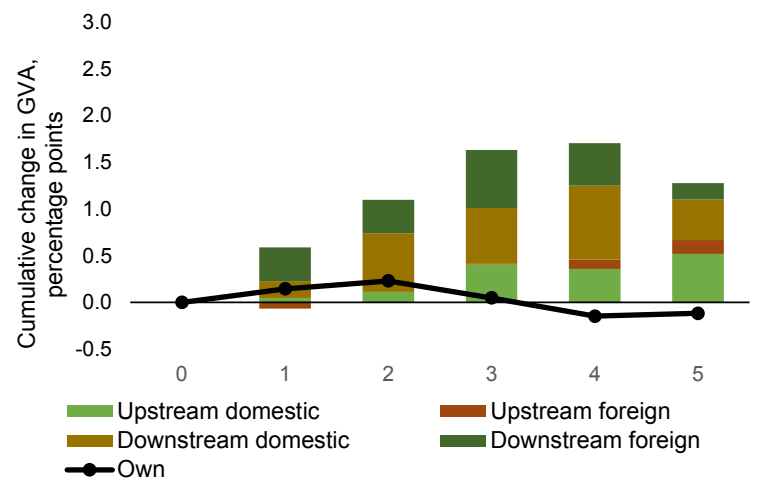

Source: Authors' calculations.

Notes: The labels for the horizons $h$ in the figure have been shifted by one period, to ease the comparison with TFP results.

\section{Historical negative sectoral shocks: sector recovery and the role of spillovers}

The analysis thus far shows that shock amplification through the sectoral structure of production can be substantial. Here we are interested in understanding to what extent, historically, sectors hit by negative shocks have recovered and whether the amount and persistence of the damage, if any, differs between own and network shocks. We focus on a sector's share in its country's GVA as a measure of sectoral performance and recovery.

When focusing on the dynamics of industries after a shock, it is important to recognize that the sectoral shocks we analyze are frequent and are likely to present an autocorrelation structure that can affect the cumulative change in outcomes after a shock experienced in any 
given period. To account for this feature of the data, in this section we derive results following a two-step approach. First, we estimate equations of the following type:

$$
\Delta Y_{s, c, t}=\sum_{h=0}^{H} \beta^{h} \operatorname{Shock}_{s, c, t-h}^{J}+\gamma_{s, c, t}+\varepsilon_{s, c, t},
$$

where $\Delta Y_{s, c, t}$ is the percent change in the share of GVA of sector $s$ in total GVA in country $c$ from time $t-1$ to $t ;{ }^{: 12}$ Shock $k_{s, c, t-h}^{J}$ is a negative TFP or government spending shock, derived as described in previous sections, with $J=O w n$, TotNwk; $\gamma_{s, c, t}$ is a set of country-time, sectortime, and country-sector fixed effects; and finally $\varepsilon_{s, c, t}$ is the error term.

In a second step, we estimate the following dynamic panel model, to recover the autocorrelation structure of the shocks:

$$
\text { Shock } k_{s, c, t}^{J}=\sum_{h=1}^{H} \theta^{h} \text { Shock }_{s, c, t-h}^{J}+\delta_{s, c, t}+\varepsilon_{s, c, t},
$$

where $\operatorname{Shock} k_{s, c, t}^{J}$ are either own $(J=O w n)$ or total network shocks $(J=T o t N w k) ; \delta_{s, c, t}$ is a set of country-time, sector-time, and country-sector fixed effects; and $\varepsilon_{s, c, t}$ is an error term.

Finally, we combine the results from (7) and (8). ${ }^{13}$ Specifically, at $h=0$ the effect of a one standard deviation shock hitting sector $s$ in country $c$ at time $t$ is equal to $\beta^{0}$; at $h=1$, the effect is $\beta^{0} \theta^{1}+\beta^{1}$; at $h=2$, it is $\beta^{0}\left(\left(\theta^{1}\right)^{2}+\theta^{2}\right)+\beta^{1} \theta^{1}+\beta^{2}$; and so on. Adding up those periodby-period effects gives the impulse response functions for the cumulative growth rate in GVA shares that we present in Figure 4.

Our results show that a sector does not recover, on average, from a productivity shock coming from its own sector, with the sectors' share of GVA remaining 5 percent lower up to five years after the shock (Figure 4, Panel 1). Government spending shocks and shocks originating in other sectors, however, do not statistically significantly affect a sector's size, although there are signs that productivity network effects may be large and long-lived (Figure 4, Panels 1 and 2). ${ }^{14}$

\footnotetext{
12 Again, we cap changes in GVA shares larger than 0.5 (smaller than -0.5$)$ at $0.5(-0.5)$.

13 Estimated coefficients for the intermediate regressions (7) and (8) are reported in Table B3 in Appendix B.

14 The COVID-19 demand shocks may have larger and more persistent effects than the typical past government spending shock, however, as they may induce permanent shifts in consumers' preferences. Studying the spillover effects from private demand shocks is an interesting avenue for future research.
} 


\section{Figure 4. Recovery from Negative Sectoral Shocks}

1) Recovery Path from Own Shocks

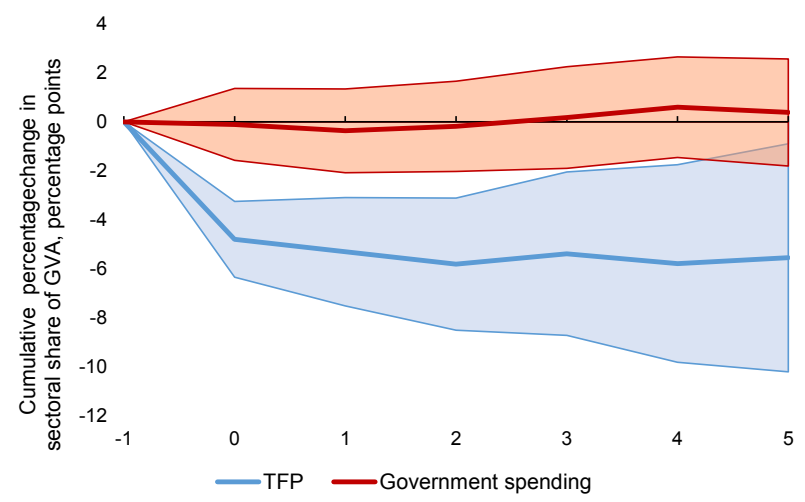

2) Recovery Path from Total Network Shocks

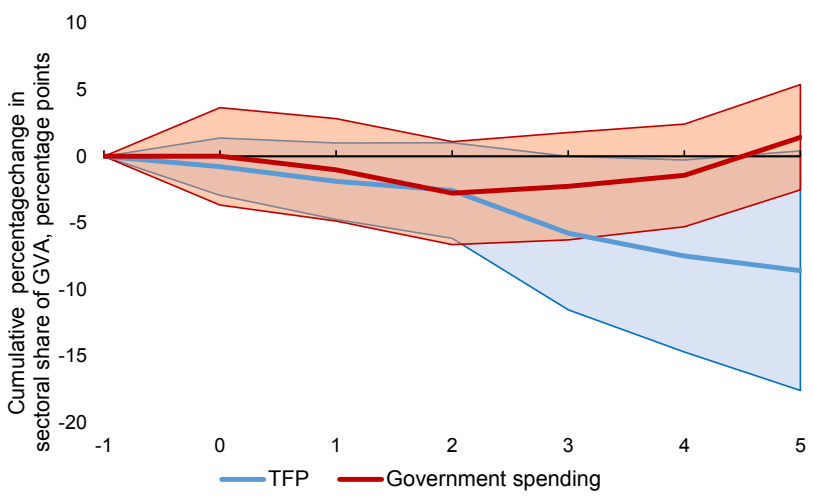

Source: Authors' calculations.

Notes: Shaded areas are 95 percent confidence intervals, adjusted so to reflect the estimation variability entailed by both (7) and (8).

\section{The sectoral dimension of the COVID-19 shock}

In this section we first discuss the demand and supply components of the COVID-19 shock at the sector level (III.A) and then turn to a quantification of the importance of spillovers from shocks originating in other sectors to a sector's activity (III.B).

\section{A. Supply and demand components of the COVID-19 shock across sectors}

Given the unique nature of the COVID-19 crisis, a brief exploration of the supply and demand shocks at play can help outline the transmission of the pandemic's economic effects and its differential impacts across sectors and countries. We group sectors into four categories based on their contact intensity and vulnerability to disruption by the pandemic (Table 1). High-contact, affected sectors have been most severely impacted by lockdowns and other pandemic containment measures, but the decline in activity was also sudden and severe in other sectors, more than during the Global Financial Crisis and other recent recessions (Figure 5). 


\title{
Table 1. Differential Impact across Sectors
}

\author{
High-contact, affected sectors \\ Effectively shut down \\ For example, hotels, restaurants, transportation, brick-and-mortal retail \\ Supply and demand collapsed simultaneously. \\ High-contact, less-affected sectors \\ Essential services and outdoor activities \\ For example, health services, grocery stores, construction \\ In some, supply was constrained and demand increased. \\ Low-contact services \\ Shifted quickly to online delivery \\ For example, professional and business services \\ Supply was largely unaffected, but demand decreased. \\ Other low-contact sectors \\ For example, manufacturing \\ Supply was constrained; demand increased or decreased depending on subsector. \\ Source: Authors.
}

Both supply and demand got a hit from COVID-19. On the supply side, lockdowns reduced effective productive capacity. Some businesses also experienced lower productivity because they had to reorganize production to increase the physical distance between workers. These initial sectoral supply shocks spilled over to affect supply in other sectors through links in production networks. ${ }^{15}$ Demand fell due to reduced mobility and as precautionary savings rose amid heightened uncertainty. The initial supply shocks also propagated to a decline in demand.${ }^{16}$ This propagation was amplified in many cases by liquidity-constrained households and firms forced to cut back on outlays, leading to more layoffs and further declines in private spending. ${ }^{17}$

\footnotetext{
${ }^{15}$ See Baqaee and Farhi (2020) for an illustration.

${ }^{16}$ See Guerrieri and others (2020) and Baqaee and Farhi (2021) for models in which supply shocks can transform into Keynesian aggregate demand shocks.

${ }^{17}$ The policy response was focused on mitigating household and firm liquidity constraints, but the number of households and firms in financial distress rose nonetheless in many countries following the COVID-19 outbreak. See Li and others (2020).
} 


\section{Figure 5. Value Added by Sector Group During Recessions}

1) High Contact Affected

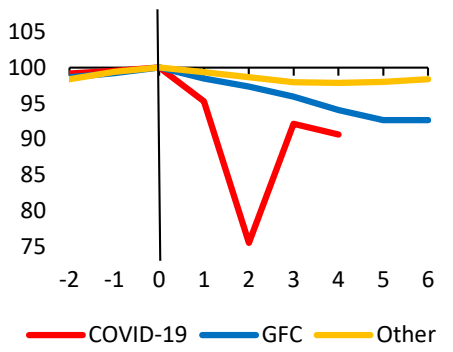

3) Low-Contact Services

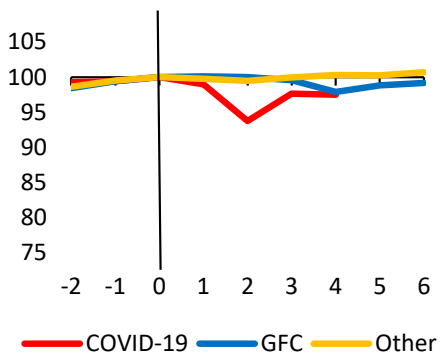

2) High Contact Less Affected

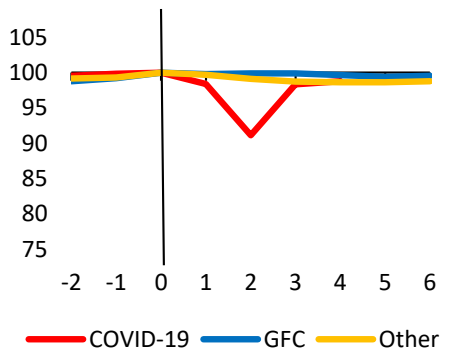

4) Low Contact, Other

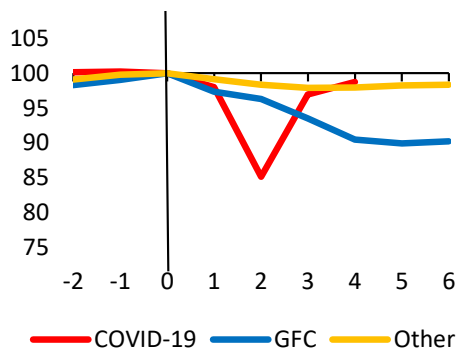

Sources: Organisation for Economic Co-Operation and Development; US Bureau of Economic Analysis; and authors' calculations.

Notes: Data are for 1990:Q1-2020:Q4 from 38 countries (the number of countries used for each recession line varies). Time since the shock (in quarters) on the $\mathrm{x}$-axis. Lines are averages weighted by country's purchasing-power-parity GDP, with quarter 0 as the last prerecession quarter. For the COVID-19 crisis, quarter 0 is 2019:Q4. For the Global Financial Crisis (GFC), quarter 0 is the country-specific date of peak real GDP during 2007-08. Other recessions are country-specific and identified by two consecutive quarters of negative growth during 1990-2006 and 2009-2019. Highcontact affected sectors are wholesale and retail trade, transportation, accommodations, arts, and other service activities; high-contact less-affected sectors are construction, public administration, education, and health care; low-contact services are information and communication, financial and insurance activities, real estate activities, and other professional and scientific activities; other low-contact sectors are agriculture, mining, manufacturing, and utilities.

Focusing on the case of the United States, for which detailed and timely data are available, a more detailed picture emerges of the relative strengths of the supply and demand forces at work. While quantities purchased initially fell across the board (Figure 6), changes in prices have been relatively muted (Figure 7, Panel 1). Price movements across four sector groupings point to differential impacts across sectors (Figure 7, Panel 2). Wider dispersion in price movements is seen, for example, among the more-affected, high-contact sectors and among services more generally. Statistical decompositions of sectoral price variation suggest that supply shocks dominated, accounting for about two-thirds of the decrease in employment and output in the United States in the second quarter of 2020 (Bekaert, Engstrom, and Ermolov, 2020; Brinca, Duarte, and Faria-e-Castro, 2020), but with large demand shocks in the food services, accommodation, and tourism sectors (del Rio-Chanona and others, 2020). 


\section{Figure 6. Consumption Patterns during COVID-19 in the US}

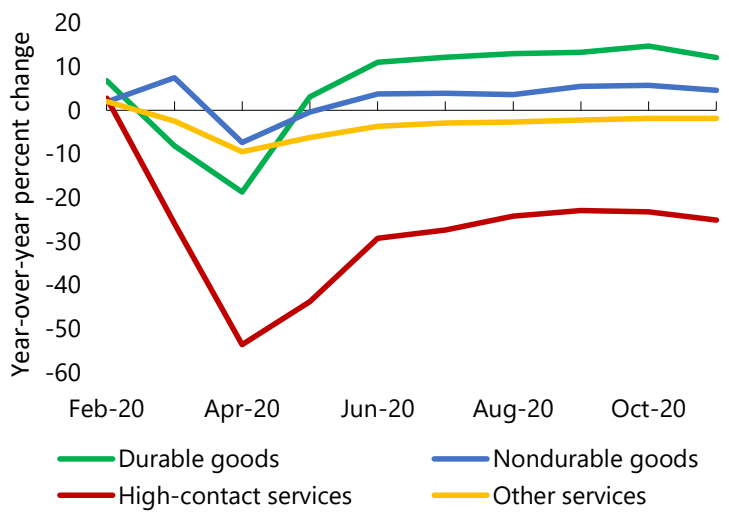

Sources: Haver Analytics; and IMF staff calculations.

Notes: High-contact services are food, accommodation, recreation, and transportation services.

Overall, the economic contraction in the first half of 2020 is best understood as a combination of a massive initial supply shock and a large decline in demand, with propagation through production networks. As the pandemichas progressed, and lockdownshave been lifted and reimposed, sometimes for narrower regions or in a less restrictive manner than in early 2020 , the supply shocks have unwound to varying degrees across sectors. The effectiveness of measures taken by businesses to adapt to the lower-contact environment has also varied across sectors, leaving the remaining supply constraints highest in the high-contact sectors.

\section{Figure 7. Sectoral Price Changes in the US}

1) Comparison with Previous Period

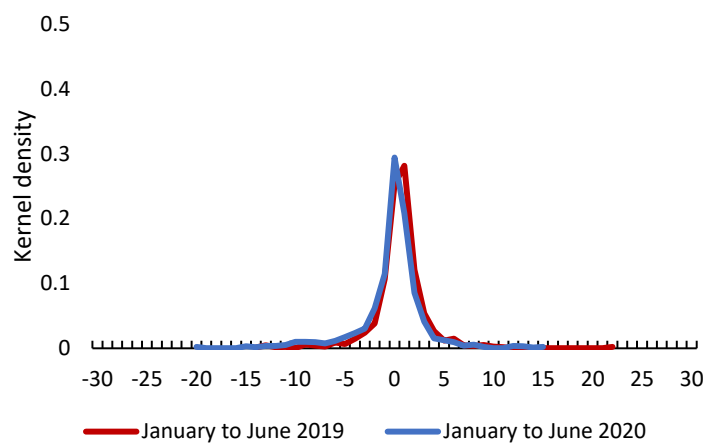

2) COVID-19 Price Changes by Sector Group

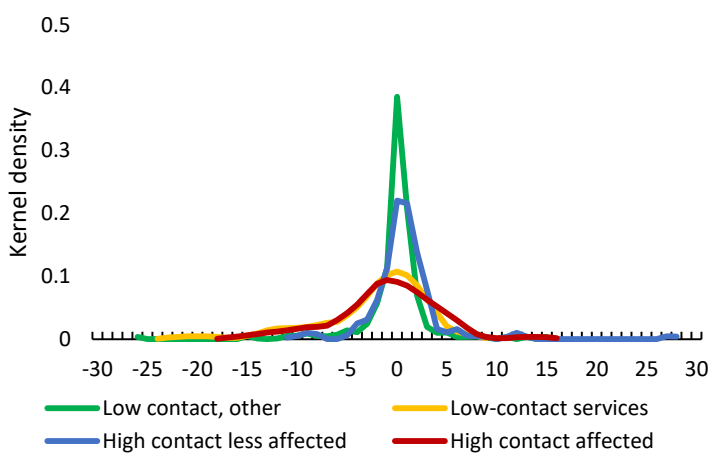

Sources: Bureau of Labor Statistics; and IMF staff calculations.

Notes: Percent change in industry-level US producer prices on X-axis. Data are for the United States. In panel 2, price changes are from January to June 2020. See Table 1 for a description of the sector groups.

The swift action taken by policymakers, especially in advanced economies, greatly helped in cushioning household income and firms' cash flows, in improving confidence, and in shielding the financial sector. Yet, the sheer size of the COVID-19 shock made it impossible 
to prevent the damage from spreading within and across countries. In the next section, we provide evidence of this transmission. ${ }^{18}$

\section{B. Sectoral Spillovers in the COVID-19 crisis}

To understand the importance of sectoral spillovers in the current crisis, we consider a backof-the envelope exercise that combines the historical coefficients estimated in the previous section, the pre-pandemic network structure of the economy, and the sectoral changes to productivity and employment observed in the first months of 2020.19

In quantifying the COVID-19 shocks to TFP and total hours worked across sectors and countries, we start by considering the difference in these variables between 2019Q4 and $2020 \mathrm{H} 1$. We then assign the change in TFP and a fraction of the change in hours to the supply component of the shock, with the remaining fraction of the change in hours being the demand component. The split of the change in hours into supply and demand is based on the level of "teleworkability" and essentiality of each sector, according to the classification in Shibata (2020). The guiding principle is that the larger the share of a sector's activity that is teleworkable and/or essential, the more the observed change in hours can be attributed to demand factors. Having obtained the supply and demand shocks for each sector and country (the own shocks, in the classification of Section II.A), we derive the network shocks according to formulas (1)-(4), using input-output tables for the year 2014 (the last available year in the WIOD dataset). Finally, we obtain own and network effects on GVA by multiplying shocks of each type by the corresponding coefficient estimated in (6). More details on our methodology can be found in Appendix C.

Results for this exercise indicate that sectoral spillovers have been significant during the current crisis, with a relative contribution of network shocks to the decline in GVA in the first year of the pandemic of about 40 percent, on average (Figure 8). ${ }^{20}$ Foreign spillovers appear to have played a more limited role, consistent with recent studies of the transmission of the COVID-19 shock through global value chains (Bonadio and others, 2020; Cerdeiro and Komaromi, 2020). ${ }^{21}$

Figure 8 also shows that, intuitively, the own effect is larger for high-contact sectors while the relative importance of spillovers is larger for low-contact sectors. The absolute size of the

\footnotetext{
${ }^{18}$ Barrett and others (forthcoming) study the prospects from economic scarring after the COVID-19 crisis and the role that policy support and economic structure play when it comes to medium-term damages.

${ }^{19}$ In this section we provide an overview of the exercise. See Appendix $\mathrm{C}$ for further methodological details.

${ }^{20}$ The fact that $\beta^{S U P, J, h}$ and $\beta^{D E M, J, h}$ are estimated from regressions in which the shocks are standardized implies that the average effects reported in Figure 8 are relative contributions to the total GVA drop. Moreover, the timing convention adopted in the estimation of historical spillovers from supply-side shocks implies that the results in the figure should be interpreted as those occurring in the aftermath of the initial COVID-19 shock.

${ }^{21}$ Bonadio and others (2020) finds that one-quarter of the average real GDP downturn caused by the COVID-19 shock was due to transmission through global supply chains, while Cerdeiro and Komaromi (2020) shows that lockdowns in early 2020 resulted in strong but short-lived trade spillovers.
} 
spillovers remains likely more modest in low-contact vis-à-vis high-contact sectors, however, as the contraction in gross value added was less severe (see Figure 5).

\section{Figure 8. Relative Own and Spillover Effects from the COVID-19 Shock}

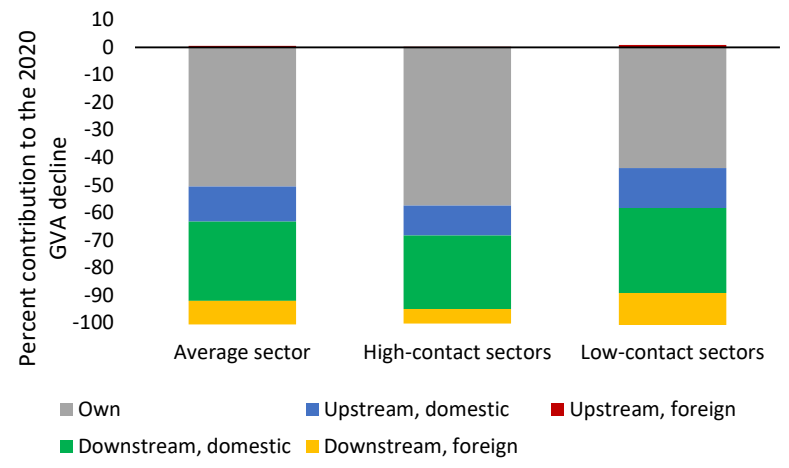

Sources: World Input-Output Database; OECD Quarterly National Accounts; International Labor Organization; and authors' calculations.

Notes: The relative effects can be interpreted as those occurring in the aftermath of the initial shock in 2020. High-contact sectors are wholesale and retail trade, hotels and restaurants, entertainment and personal services, transportation, education, health, and construction. Low-contact sectors are all the others. Effects are reported with the reverse sign. Sample covers up to 34 countries (24 advanced and 10 emerging markets) over 1995-2014. GVA = gross value added.

Note that, while still sizable, the relative size of sectoral spillovers compared with own effects is smaller for COVID-19 than for past productivity and government spending shocks. The difference results from the pandemic shock's origin in sectors that are more peripheral to production networks (predominantly services) than those affected by the past shocks we consider. However, the sheer magnitude of the COVID-19 shock, especially for countries with large sectoral exposure, means that the absolute impact of spillovers on the overall decline in activity is likely substantial, even if their relative importance is somewhat more limited than for past shocks.

Moreover, the longer the crisis continues - and if the number of small business failures climbs - the greater the likelihood the shock will spread even more widely across economies. From closed restaurants and bars, to farms and wineries shutting down, to lower demand for tractors and other agricultural equipment, damage to high-contact sectors will continue to spill over to other sectors and countries.

\section{Conclusions and Policy Implications}

Our analysis of historical sector-level shocks, both domestic and foreign, reveals sizable and persistent sectoral spillovers on economic activity from both supply and demand shocks, in a broad sample of countries. Negative sectoral productivity shocks, in particular, appear to 
have persistent effects, leading to long-lasting declines, on average, in the sectors they have struck.

When considering the pandemic in 2020, the unusual combination of supply and demand shocks hitting sectors as policymakers implemented virus containment measures raises the question of the relative importance of spillovers to other sectors and countries. Building upon the historical relationships we estimate and the existing production structure of economies, we find that sectoral spillovers have meaningfully amplified the COVID-19 shock as well. The relative size of sectoral spillovers (compared to the effect of a shock originating within a sector) is smaller for the COVID-19 shock than in the past, since the high-contact sectors are less central to production networks. However, spillover effects stemming from the COVID-19 shock were still sizeable and made up a significant fraction of the overall decline in activity in the first year of the pandemic. Moreover, the lack of recovery of sectors, on average, after past negative productivity shocks underscores the potential for a permanent decline of the sectors most affected by the COVID-19 crisis.

Overall, our results confirm the importance of network-based propagation in amplifying macroeconomic fluctuations, with a number of implications for policymakers and future research. First, by limiting sectoral spillovers, targeted support to firms in hard-hit sectors can have outsized effects in mitigating output losses early on in a crisis. Second, as sectors historically do not fully recover following large negative shocks, there are potentially high returns from policies that facilitate the reallocation of capital and workers to other sectors. Finally, our results highlight the importance of considering amplification and transmission effects in the design of policies with a sectoral dimension. Spillovers are likely to arise, for example, in the context of the transition to a low-carbon economy, or in the allocation of sectorspecific public investment. Further research into the propagation of other types of shocks, especially those emanating from sector-specific policy changes, would help policy makers prepare to deal with negative spillovers and to leverage positive ones. 


\section{References}

Acemoglu, Daron, Ufuk Akcigit, and William Kerr. 2016. "Networks and the Macroeconomy: An Empirical Exploration.” NBER Macroeconomics Annual 30 (1): 273-335.

Acemoglu, Daron, David Autor, David Dorn, Gordon H. Hanson, and Brendan Price. 2016. "Import Competition and the Great US Employment Sag of the 2000s." Journal of Labor Economics 34 (S1): S141-98.

Acemoglu, Daron, Vasco M. Carvalho, Asuman Ozdaglar, and Alireza Tahbaz-Salehi. 2012. “The Network Origins of Aggregate Fluctuations." Econometrica 80(5): 1977-2016.

Acemoglu, Daron, Asuman Ozdaglar, and Alireza Tahbaz-Salehi. 2017. "Microeconomic origins of macroeconomic tail risks." American Economic Review 107(1): 54-108.

Atalay, Enghin. 2017. "How Important are Sectoral Shocks?" American Economic Journal: Macroeconomics 9(4): 254-280.

Baqaee, David R., and EmmanuelFarhi. 2019 “The Macroeconomic Impact of Microeconomic Shocks: Beyond Hulten's Theorem.” Econometrica 87(4): 1155-1203.

Baqaee, David R., and Emmanuel Farhi. 2020. "Nonlinear Production Networks with an Application to the COVID-19 Crisis." NBER Working Paper 27281, National Bureau of Economic Research, Cambridge, MA.

Baqaee, David R., and Emmanuel Farhi. 2021. "Supply and Demand in Disaggregated Keynesian Economies with an Application to the Covid-19 Crisis." Unpublished.

Barrot, Jean-Noel and Julien Sauvagnat. 2016. "Input Specificity and the Propagation of Idiosyncratic Shocks in Production Networks." The Quarterly Journal of Economics 131(3): 1543-1592.

Bekaert, Geert, Eric Engstrom, and Andrey Ermolov. 2020. "Aggregate Demand and Aggregate Supply Effects of COVID-19: A Real-Time Analysis.” Finance and Economics Discussion Series 2020-049, Board of Governors of the Federal Reserve System.

Boehm, Christoph E., Aaron Flaaen, and Nitya Pandalai-Nayar. 2019. "Input Linkages and the Transmission of Shocks: Firm-level Evidence from the 2011 Tōhoku Earthquake." Review of Economics and Statistics 101(1): 60-75.

Bonadio, Barthélémy, Zhen Huo, Andrei A. Levchenko, and Nitya Pandalai-Nayar. 2020. "Global Supply Chains in the Pandemic." NBER Working Paper 27224, National Bureau of Economic Research, Cambridge, MA.

Brinca, Pedro, João B. Duarte, and Miguel Faria-e-Castro. 2020. "Measuring Sectoral Supply and Demand Shocks during COVID-19.” Covid Economics 20. London: CEPR Press.

Carvalho, Vasco M. and Alireza Tahbaz-Salehi. 2019. "Production Networks: A Primer." Annual Review of Economics 11:635-663. 
Carvalho, Vasco M., Makoto Nirei, Yukiko U. Saito, and Alireza Tahbaz-Salehi. 2021. "Supply Chain Disruptions: Evidence from the Great East Japan Earthquake." The Quarterly Journal of Economics 136(2): 1255-1321.

Cerdeiro, Diego, and Andras Komaromi. 2020. "Supply Spillovers during the Pandemic: Evidence from High-Frequency Shipping Data." IMF Working Paper 2020/284, International Monetary Fund, Washington, DC.

Barrett, Philip, Sonali Das, Giacomo Magistretti, Evgenia Pugacheva, Philippe Wingender. Forthcoming. "After-Effects of the COVID-19 Pandemic: Prospects for Medium-Term Economic Damage.” IMF Working Paper, International Monetary Fund, Washington, DC.

del Rio-Chanona, R. Maria, Penny Mealy, Anton Pichler, François Lafond, and J. Doyne Farmer. 2020. "Supply and Demand Shocks in the COVID-19 Pandemic: An Industry and Occupation Perspective." Oxford Review of Economic Policy 36 (Supplement): 94-137.

Di Giovanni, Julian, Andrei A. Levchenko, and Isabelle Mejean. 2014. "Firms, Destinations, and Aggregate Fluctuations.” Econometrica 82(4): 1303-1340.

Foerster, Andrew T., Pierre-Daniel G. Sarte, and Mark W. Watson. 2011. "Sectoral versus Aggregate Shocks: A Structural Factor Analysis of Industrial Production." Journal of Political Economy 119(1): 1-38.

Guerrieri, Veronica, Guido Lorenzoni, Ludwig Straub, and Iván Werning. 2020. "Macroeconomic Implications of COVID-19: Can Negative Supply Shocks Cause Demand Shortages?" NBER Working Paper 26918, National Bureau of Economic Research, Cambridge, MA.

Jordà, Òscar. 2005. "Estimation and Inference of Impulse Responses by Local Projections." American Economic Review 95 (1): 161-182.

Hulten, Charles R. 1978. "Growth Accounting with Intermediate Inputs." The Review of Economic Studies 45(3): 511-518.

Leontief, Wassily W. 1951. The Structure of American Economy, 1919-1939: An Empirical Application of Equilibrium Analysis. Oxford University Press, New York, NY.

Li, Jie, Quanyun Song, Changyan Peng, and Yu Wu. 2020. "COVID-19 Pandemic and Household Liquidity Constraints: Evidence from Micro Data." Emerging Markets Finance and Trade 56 (15): 3626-34.

Long, John B. and Charles I. Plosser. 1983. "Real Business Cycles." Journal of Political Economy 91(1): 39-69.

Shibata, Ippei. 2020. “The Distributional Impact of Recessions: The Global Financial Crisis and the Pandemic Recession." IMF Working Paper 20/96, International Monetary Fund, Washington, DC.

Timmer, Marcel P., Erik Dietzenbacher, Bart Los, Robert Stehrer, and Gaaitzen J. de Vries. 2015. "An Illustrated User Guide to the World Input-Output Database: The Case of Global Automotive Production." Review of International Economics 23: 575-605. 


\section{Appendix A. Data coverage}

\section{Table A1. Sectors Considered in the Analysis of Productivity and Government Spending Shocks}

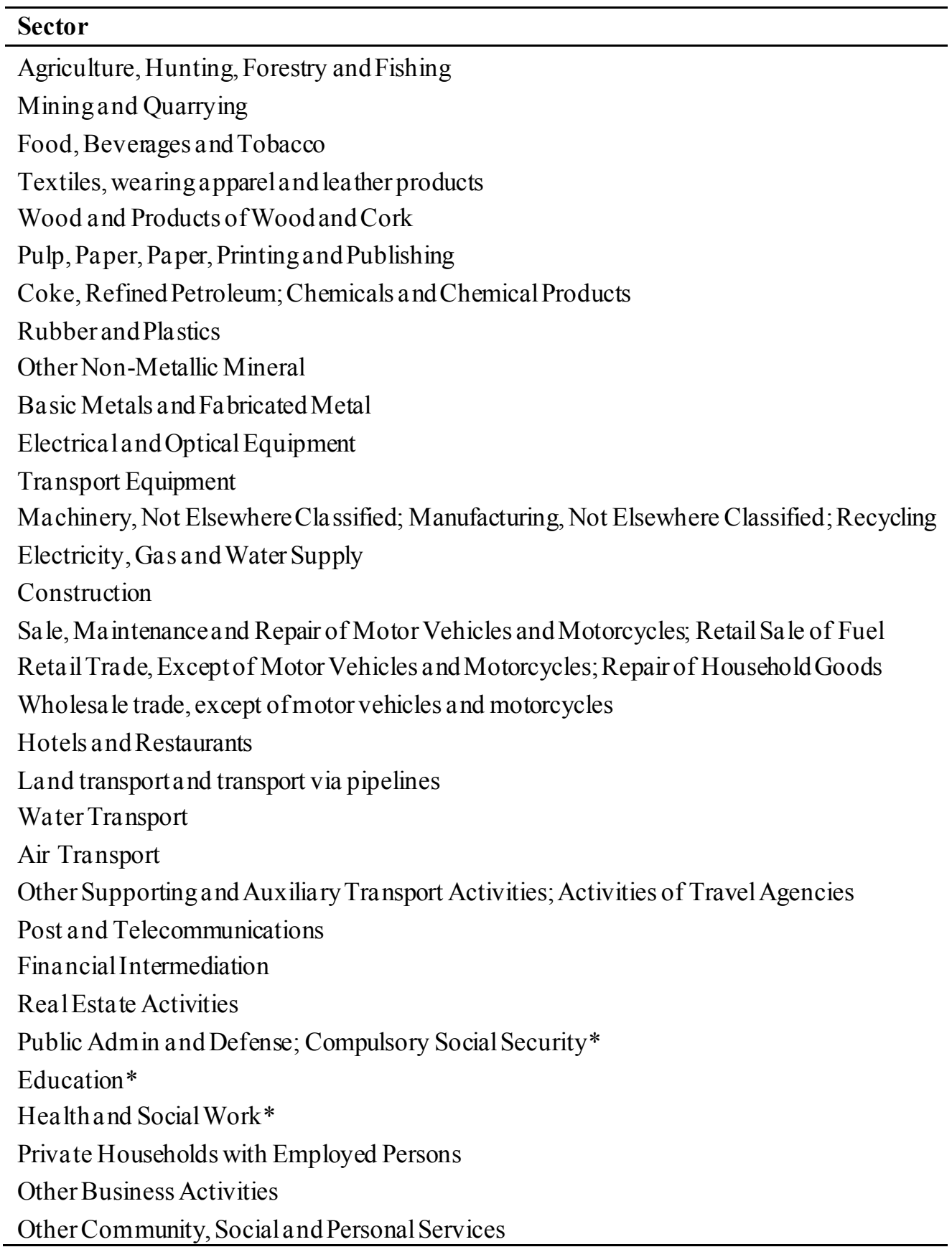

Notes: Reclassification of the sectors in the 2013 and 2016 releases of WIOD data. Stars denote sectors excluded from the analysis of government spending shocks. 


\section{Table A2. Country Coverage}

\begin{tabular}{ll}
\hline Exercise & List of Economies \\
\hline & Australia; Austria; Belgium; Brazil; Bulgaria; Canada; China; Croatia*; Cyprus; \\
Spillovers from past & Czech Republic; Denmark; Estonia; Finland; France; Germany; Greece; \\
TFP and government & Hungary; India; Indonesia; Ireland; Italy; Japan; Korea; Latvia; Lithuania; \\
spending shocks & Luxembourg; Malta; Mexico; Netherlands; Norway*; Poland;Portugal; \\
& Romania; Russia; Slovak Republic; Slovenia; Spain; Sweden; Switzerland*; \\
& Taiwan Province of China; Turkey; United Kingdom; United States \\
& Australia; Austria; Belgium;Brazil; Canada; China;Czech Republic; Denmark; \\
& Finland; France; Germany; Greece; Hungary; India;Indonesia; Ireland;Italy; \\
COVID-19 spillovers & Japan; Korea; Mexico; Netherlands; Norway; Poland;Portugal; Romania; \\
& Russia; Slovak Republic; Spain; Sweden; Switzerland; Taiwan Province of \\
& China;Turkey;United Kingdom;United States \\
\hline
\end{tabular}

Notes: Stars denote countries included in the a nalysis of government spending shocks only. 


\section{Appendix B. Additional results}

Table B1. Effects of Supply-Side Productivity Shock

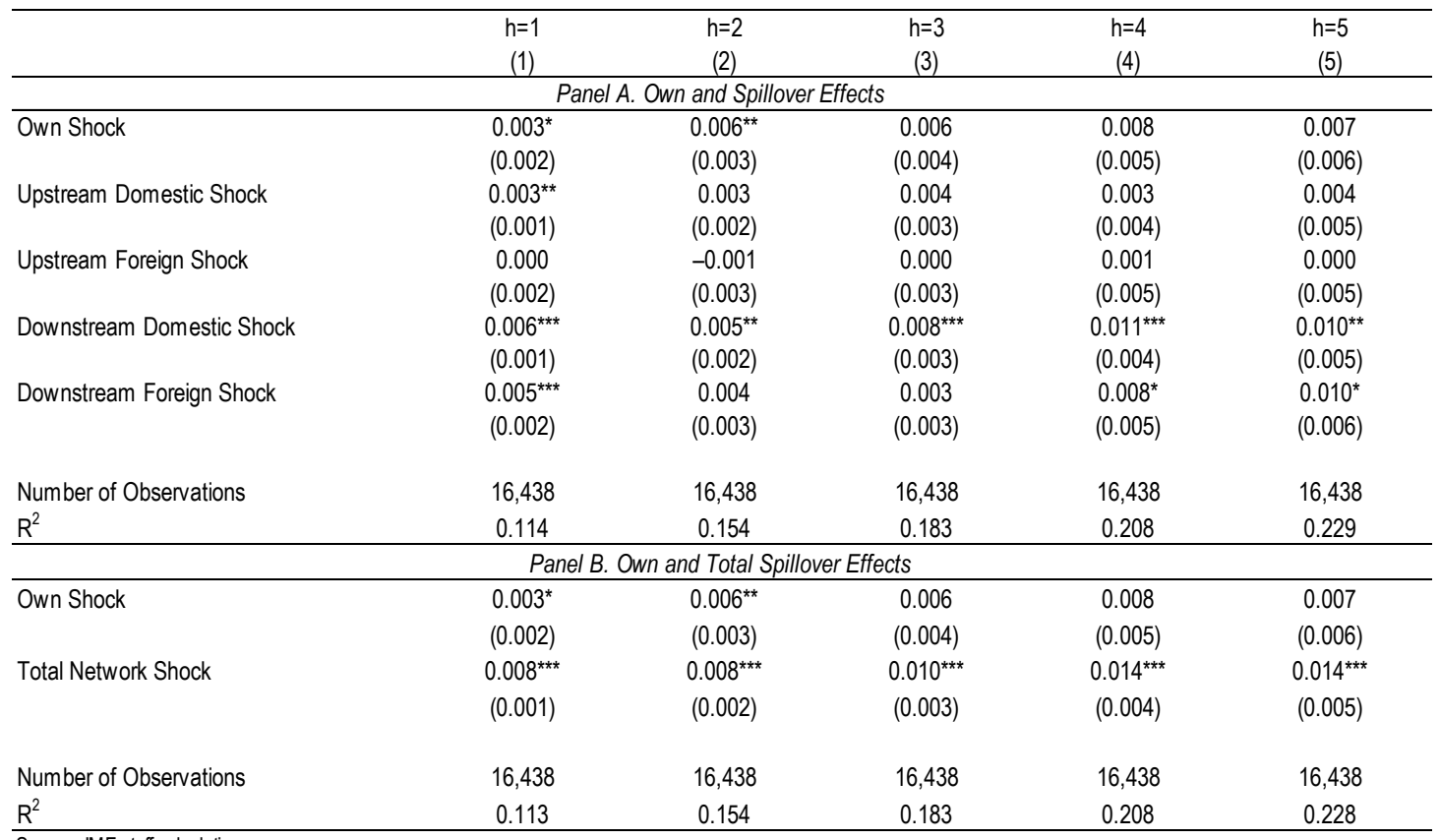

Source: IMF staff calculations.

Note: The dependent variables are cumulative growth of real GVA at horizon $h$ after a shock. Shocks are changes in sectoral TFP originated in Own sector or in other sectors in the production network, as described in the text. Total Network Shock is the sum of the four types of network shocks. Every shock is divided by its standard deviation. Regressions are estimated separately for each horizon. The sample covers 29 advanced and 11 emerging economies over 1995-2009 (see Annex Table 2.1.2). All regressions include country, sector, and year fixed effects. Standard errors are clustered at the country-sector level. * $p<0.1 ;{ }^{* *} p<0.05 ;{ }^{* * *} p<0.01$.

Table B2. Effects of Demand-Side Government Spending Shocks

\begin{tabular}{|c|c|c|c|c|c|}
\hline & $\begin{array}{c}\mathrm{h}=0 \\
(1)\end{array}$ & $h=1$ & $\mathrm{~h}=2$ & $\mathrm{~h}=3$ & $\mathrm{~h}=4$ \\
\hline \multicolumn{6}{|c|}{ Panel A. Own and Spillover Effects } \\
\hline Own Shock & $\begin{array}{c}0.001 \\
(0.001)\end{array}$ & $\begin{array}{c}0.002 \\
(0.001)\end{array}$ & $\begin{array}{l}-0.001 \\
(0.002)\end{array}$ & $\begin{array}{l}-0.001 \\
(0.003)\end{array}$ & $\begin{array}{l}-0.001 \\
(0.005)\end{array}$ \\
\hline Upstream Domestic Shock & $\begin{array}{c}0.000 \\
(0.001)\end{array}$ & $\begin{array}{c}0.001 \\
(0.003)\end{array}$ & $\begin{array}{c}0.004 \\
(0.005)\end{array}$ & $\begin{array}{c}0.004 \\
(0.008)\end{array}$ & $\begin{array}{c}0.005 \\
(0.010)\end{array}$ \\
\hline Upstream Foreign Shock & $\begin{array}{l}-0.001 \\
(0.002)\end{array}$ & $\begin{array}{c}0.000 \\
(0.002)\end{array}$ & $\begin{array}{c}0.000 \\
(0.003)\end{array}$ & $\begin{array}{c}0.001 \\
(0.004)\end{array}$ & $\begin{array}{c}0.001 \\
(0.005)\end{array}$ \\
\hline Downstream Domestic Shock & $\begin{array}{c}0.002 \\
(0.002)\end{array}$ & $\begin{array}{l}0.006^{* *} \\
(0.003)\end{array}$ & $\begin{array}{c}0.006 \\
(0.005)\end{array}$ & $\begin{array}{c}0.008 \\
(0.007)\end{array}$ & $\begin{array}{c}0.004 \\
(0.010)\end{array}$ \\
\hline Downstream Foreign Shock & $\begin{array}{l}0.004^{* *} \\
(0.001)\end{array}$ & $\begin{array}{l}0.004^{*} \\
(0.002)\end{array}$ & $\begin{array}{l}0.006^{\star *} \\
(0.003)\end{array}$ & $\begin{array}{c}0.005 \\
(0.004)\end{array}$ & $\begin{array}{c}0.002 \\
(0.006)\end{array}$ \\
\hline Number of Observations & 22,972 & 21,738 & 20,504 & 19,270 & 18,036 \\
\hline $\mathrm{R}^{2}$ & 0.110 & 0.173 & 0.187 & 0.208 & 0.230 \\
\hline \multicolumn{6}{|c|}{ Panel B. Own and Total Spillover Effects } \\
\hline Own Shock & $\begin{array}{c}0.001 \\
(0.001)\end{array}$ & $\begin{array}{c}0.003^{*} \\
(0.001)\end{array}$ & $\begin{array}{c}0.001 \\
(0.002)\end{array}$ & $\begin{array}{l}-0.001 \\
(0.003)\end{array}$ & $\begin{array}{l}-0.001 \\
(0.005)\end{array}$ \\
\hline Total Network Shock & $\begin{array}{c}0.002 \\
(0.001)\end{array}$ & $\begin{array}{c}0.006^{* * *} \\
(0.002)\end{array}$ & $\begin{array}{c}0.009^{\star \star \star} \\
(0.003)\end{array}$ & $\begin{array}{l}0.010^{* *} \\
(0.004)\end{array}$ & $\begin{array}{c}0.009 \\
(0.006)\end{array}$ \\
\hline Number of Observations & 22,972 & 21,738 & 20,504 & 19,270 & 18,036 \\
\hline $\mathrm{R}^{2}$ & 0.109 & 0.172 & 0.187 & 0.208 & 0.230 \\
\hline
\end{tabular}

Source: IMF staff calculations.

Note: The dependent variables are cumulative growth of real GVA at horizon $h$ after a shock. Shocks are changes in sectoral government spending originated in Own sector or in other sectors in the production network, as described in the text. Total Network Shock is the sum of the four types of network shocks. Every shock is divided by its standard deviation. Regressions are estimated separately for each horizon. The sample covers 31 advanced and 12 emerging economies over 1995-2014 (see Annex Table 2.1.2). All regressions include country, sector, and year fixed effects. Standard errors are clustered at the country-sector level. ${ }^{*} p<0.1 ;{ }^{* *} p<0.05 ;{ }^{* * *} p<0.01$. 
Table B3. Intermediate Steps in the Estimation of Sector Recovery

\begin{tabular}{|c|c|c|c|c|c|c|c|c|}
\hline & \multicolumn{2}{|c|}{ TFP - Own } & \multicolumn{2}{|c|}{ TFP - TotNwk } & \multicolumn{2}{|c|}{ Gov Spend - Own } & \multicolumn{2}{|c|}{ Gov Spend - TotNwk } \\
\hline & (1) & (2) & (3) & (4) & (5) & $(6)$ & $(7)$ & (8) \\
\hline Shock, lag 0 & $\begin{array}{c}0.048^{\star \star \star} \\
(0.006)\end{array}$ & & $\begin{array}{c}0.008 \\
(0.011)\end{array}$ & & $\begin{array}{c}0.001 \\
(0.008)\end{array}$ & & $\begin{array}{c}0.000 \\
(0.012)\end{array}$ & \\
\hline Shock, lag 1 & $\begin{array}{l}0.012^{* *} \\
(0.006)\end{array}$ & $\begin{array}{c}-0.152^{\star * *} \\
(0.033)\end{array}$ & $\begin{array}{c}0.011 \\
(0.010)\end{array}$ & $\begin{array}{l}-0.025 \\
(0.037)\end{array}$ & $\begin{array}{c}0.003 \\
(0.004)\end{array}$ & $\begin{array}{l}-0.007 \\
(0.013)\end{array}$ & $\begin{array}{c}0.010 \\
(0.007)\end{array}$ & $\begin{array}{c}-0.052^{* \star *} \\
(0.015)\end{array}$ \\
\hline Shock, lag 2 & $\begin{array}{l}0.015^{* *} \\
(0.006)\end{array}$ & $\begin{array}{c}-0.190^{* * *} \\
(0.035)\end{array}$ & $\begin{array}{c}0.007 \\
(0.011)\end{array}$ & $\begin{array}{c}0.031 \\
(0.041)\end{array}$ & $\begin{array}{l}-0.002 \\
(0.005)\end{array}$ & $\begin{array}{c}0.002 \\
(0.014)\end{array}$ & $\begin{array}{c}0.018^{* * *} \\
(0.007)\end{array}$ & $\begin{array}{c}-0.129^{* * *} \\
(0.014)\end{array}$ \\
\hline Shock, lag 3 & $\begin{array}{c}0.009 \\
(0.007)\end{array}$ & $\begin{array}{c}-0.239^{\star \star \star} \\
(0.040)\end{array}$ & $\begin{array}{l}0.033^{\star \star *} \\
(0.012)\end{array}$ & $\begin{array}{c}-0.110^{\star *} \\
(0.044)\end{array}$ & $\begin{array}{l}-0.003 \\
(0.005)\end{array}$ & $\begin{array}{c}-0.140^{* \star *} \\
(0.015)\end{array}$ & $\begin{array}{l}-0.003 \\
(0.006)\end{array}$ & $\begin{array}{c}-0.105^{\star \star *} \\
(0.013)\end{array}$ \\
\hline Shock, lag 4 & $\begin{array}{l}0.014^{\star *} \\
(0.006)\end{array}$ & $\begin{array}{c}-0.183^{\star \star *} \\
(0.038)\end{array}$ & $\begin{array}{c}0.018 \\
(0.012)\end{array}$ & $\begin{array}{c}0.064 \\
(0.043)\end{array}$ & $\begin{array}{l}-0.004 \\
(0.005)\end{array}$ & $\begin{array}{c}-0.204^{\star \star *} \\
(0.015)\end{array}$ & $\begin{array}{l}-0.005 \\
(0.008)\end{array}$ & $\begin{array}{c}-0.253^{\star \star *} \\
(0.016)\end{array}$ \\
\hline Shock, lag 5 & $\begin{array}{l}0.010^{*} \\
(0.006)\end{array}$ & $\begin{array}{c}-0.225^{\star \star *} \\
(0.037)\end{array}$ & $\begin{array}{c}0.011 \\
(0.013)\end{array}$ & $\begin{array}{c}-0.115^{\star *} \\
(0.048)\end{array}$ & $\begin{array}{c}0.002 \\
(0.005)\end{array}$ & $\begin{array}{c}-0.056^{* * *} \\
(0.015)\end{array}$ & $\begin{array}{c}-0.025^{\star \star \star} \\
(0.007)\end{array}$ & $\begin{array}{c}-0.100^{* * *} \\
(0.015)\end{array}$ \\
\hline Shock, lag 6 & $\begin{array}{l}0.012^{*} \\
(0.006)\end{array}$ & $\begin{array}{c}-0.187^{\star \star *} \\
(0.036)\end{array}$ & $\begin{array}{l}-0.008 \\
(0.013)\end{array}$ & $\begin{array}{c}-0.142^{\star \star *} \\
(0.049)\end{array}$ & $\begin{array}{l}-0.004 \\
(0.007)\end{array}$ & $\begin{array}{l}0.038^{*} \\
(0.020)\end{array}$ & $\begin{array}{l}-0.003 \\
(0.011)\end{array}$ & $\begin{array}{c}-0.054^{* *} \\
(0.023)\end{array}$ \\
\hline Shock, lag 7 & $\begin{array}{c}0.001 \\
(0.006)\end{array}$ & $\begin{array}{c}-0.107^{\star * *} \\
(0.034)\end{array}$ & $\begin{array}{l}-0.003 \\
(0.011)\end{array}$ & $\begin{array}{c}-0.107^{* *} \\
(0.042)\end{array}$ & $\begin{array}{l}-0.002 \\
(0.005)\end{array}$ & $\begin{array}{c}-0.065^{\star \star \star} \\
(0.013)\end{array}$ & $\begin{array}{l}0.021^{* *} \\
(0.009)\end{array}$ & $\begin{array}{c}0.014 \\
(0.019)\end{array}$ \\
\hline Shock, lag 8 & $\begin{array}{c}0.003 \\
(0.006)\end{array}$ & $\begin{array}{l}-0.064^{*} \\
(0.034)\end{array}$ & $\begin{array}{c}0.005 \\
(0.012)\end{array}$ & $\begin{array}{l}-0.074^{*} \\
(0.045)\end{array}$ & $\begin{array}{c}0.000 \\
(0.004)\end{array}$ & $\begin{array}{c}-0.025^{* *} \\
(0.010)\end{array}$ & $\begin{array}{l}-0.004 \\
(0.006)\end{array}$ & $\begin{array}{c}0.090^{* * *} \\
(0.013)\end{array}$ \\
\hline Shock, lag 9 & $\begin{array}{l}0.009^{*} \\
(0.005)\end{array}$ & $\begin{array}{c}0.009 \\
(0.030)\end{array}$ & $\begin{array}{c}0.009 \\
(0.012)\end{array}$ & $\begin{array}{c}-0.177^{* * *} \\
(0.045)\end{array}$ & $\begin{array}{l}-0.003 \\
(0.003)\end{array}$ & $\begin{array}{c}-0.128^{* * *} \\
(0.008)\end{array}$ & $\begin{array}{c}0.003 \\
(0.006)\end{array}$ & $\begin{array}{c}-0.261^{* \star *} \\
(0.011)\end{array}$ \\
\hline Shock, lag 10 & $\begin{array}{c}0.013^{\star \star \star} \\
(0.004)\end{array}$ & $\begin{array}{l}-0.020 \\
(0.025)\end{array}$ & $\begin{array}{c}0.006 \\
(0.010)\end{array}$ & $\begin{array}{c}-0.198^{\star \star \star} \\
(0.037)\end{array}$ & $\begin{array}{c}0.001 \\
(0.003)\end{array}$ & $\begin{array}{c}-0.087^{\star * *} \\
(0.008)\end{array}$ & $\begin{array}{l}-0.008 \\
(0.005)\end{array}$ & $\begin{array}{c}-0.211^{\star \star \star} \\
(0.010)\end{array}$ \\
\hline Number of Observations & 1,558 & 1,558 & 1,344 & 1,346 & 2,621 & 2,621 & 2,534 & 2,534 \\
\hline $\mathrm{R}^{2}$ & 0.560 & 0.710 & 0.543 & 0.895 & 0.414 & 0.888 & 0.463 & 0.964 \\
\hline
\end{tabular}

\section{Appendix C. Construction of the COVID-19 shocks}

This appendix describes the methodology we follow to quantify the spillover effects during the first year of the COVID-19 pandemic. The starting point is the quantification of COVID19 shocks to TFP $\left(\Delta \log T F P_{s, c}\right)$ and total hours worked $\left(\Delta \log L_{s, c}\right)$, which we calibrate for each sector $s$ in country $c$ by considering changes in the corresponding data between 2019Q4 and $2020 \mathrm{H} 1$. Total sectoral hours worked are derived from mean weekly hours worked and employment levels from ILOSTAT. Changes in TFP are proxied by changes in labor productivity, calculated as $\Delta \log T F P_{s, c}=\Delta \log G V A_{s, c}-\Delta \log L_{s, c}{ }^{22}$ Changes in sectoral GVA are from the OECD's Quarterly National Accounts statistics. Missing data are extrapolated using sector and country income group averages.

We assume that the change in TFP is a supply-side shock. We instead partition the change in hours worked into a supply component and a demand component, according to the share of activities in a sector that are expected to be affected by COVID-19 containment measures. In particular, we recover the demand component looking at the portion of a sector's activity that can be performed through telework and/or that is essential to the economy. The rationale for this choice is that the less the activity in a sector is expected to be impacted by COVID-19

22 This effectively assumes unchanged capital. 
restrictions (because essential and/or potentially conducted remotely), the more any observed drop in labor utilization in that sector can be attributed to demand rather than supply factors. The opposite is true for sectors whose activity is largely affected by lockdowns, for which the decline in employment is then more linked to supply-side factors. Specifically, we define the share of activity affected by COVID-19 restrictions in each sector as:

$$
\alpha_{s, c}=\left(1-\text { share of telework }_{\mathrm{s}, \mathrm{c}}\right) \times\left(1-\text { share of essential }_{\mathrm{s}, \mathrm{c}}\right),
$$

based on the classification of sectors in the United States provided in Shibata (2020). These shares are assumed to be constant across countries. Figure C1 shows the values of $\alpha_{s}$. On the one hand, essential sectors - such as agriculture-or sectors with a high degree of teleworkability - such as finance - show very low values of $\alpha_{s}$, and hence we attribute most of the observed change in hours to demand factors. On the other hand, non-essential sectors with a low degree of teleworkability — such as hospitality or construction — display high values of $\alpha_{s}$, and hence we trace changes in hours mostly back to supply.

The sectoral supply and demand shocks derived with this methodology for each sector and country are "own shocks", using the terminology introduced in Section II.A. We build the corresponding network shocks to productivity and labor by applying formulas (1)-(4), based on input-output tables for the year 2014 (the last available period in the WIOD dataset).

Figure C1. Share of Activity Impacted by COVID-19

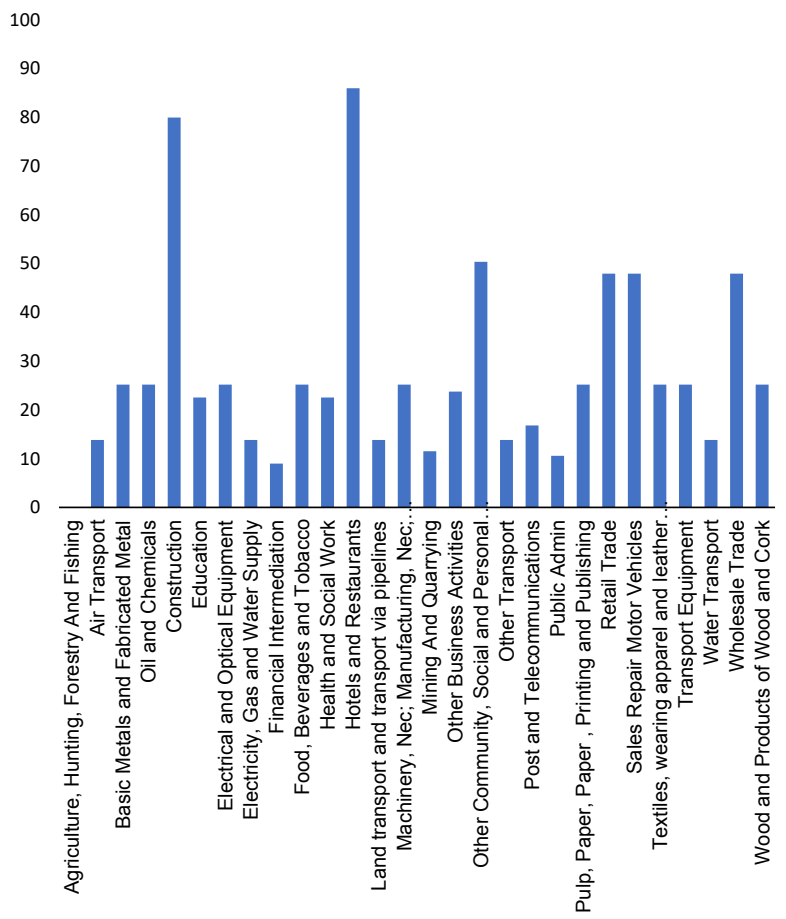

Sources: Shibata (2020); and authors' calculations.

Notes: The shares reflect the degree of teleworkability and essentiality of each sector's activity. They are assumed to be the same across countries. 
The final step in the exercise is to recover the effects of own and network shocks on sectoral real GVA as:

$$
\text { Effect }_{s, c}^{J}=\beta^{S U P, J, 1}\left(\Delta \log T F P_{s, c}^{J}+\alpha_{s} \Delta \log L_{s, c}^{J}\right)+\beta^{D E M, J, 0}\left(1-\alpha_{s}\right) \Delta \log L_{s, c}^{J},
$$

where $\beta^{S U P, J, 1}$ are the supply-side coefficients estimated for historical TFP shocks (Table B1, Panel A) and $\beta^{D E M, J, 0}$ are the demand-side coefficients estimated for historical government spending shocks (Table B2, Panel A) for shocks of type $J=O w n, U p D, U p F, D n D, D n F$. 